PREPARED FOR THE U.S. DEPARTMENT OF ENERGY, UNDER CONTRACT DE-AC02-76CH03073

PPPL-3990

PPPL-3990

UC-70

August 2004

images of Complex Interactions

of an Intense Ion Beam with Plasma Electrons

by

Igor D. Kaganovich, Edward Startsev

and Ronald C. Davidson

NM|

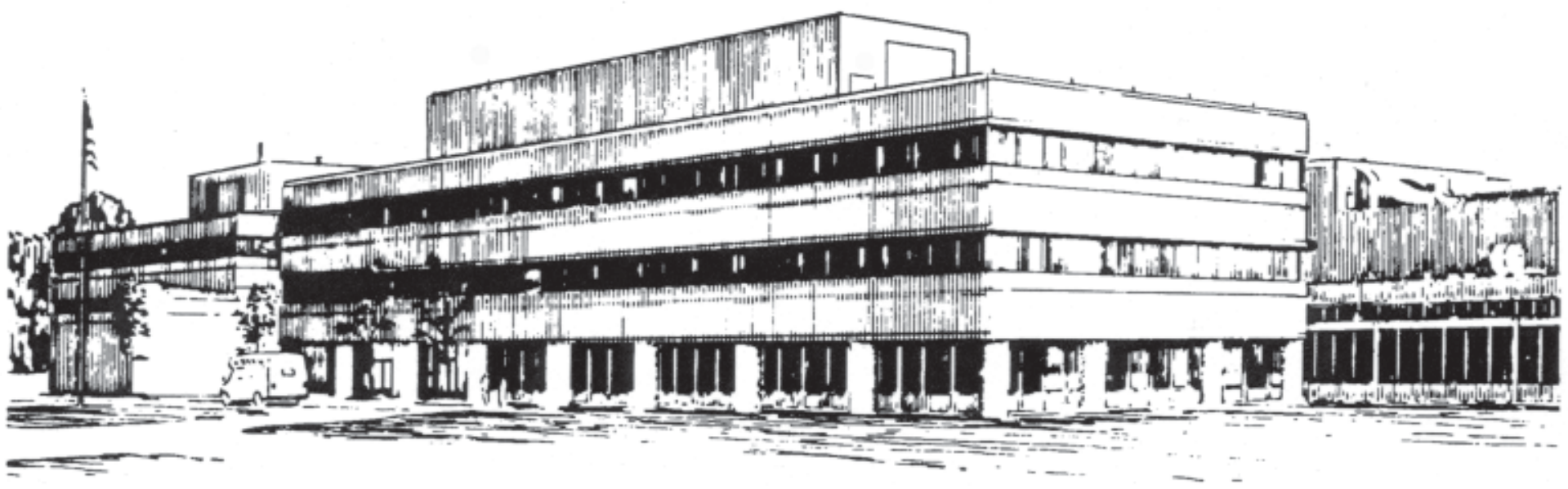

PRINCETON PLASMA PHYSICS LABORATORY PRINCETON UNIVERSITY, PRINCETON, NEW JERSEY 


\section{PPPL Reports Disclaimer}

This report was prepared as an account of work sponsored by an agency of the United States Government. Neither the United States Government nor any agency thereof, nor any of their employees, makes any warranty, express or implied, or assumes any legal liability or responsibility for the accuracy, completeness, or usefulness of any information, apparatus, product, or process disclosed, or represents that its use would not infringe privately owned rights. Reference herein to any specific commercial product, process, or service by trade name, trademark, manufacturer, or otherwise, does not necessarily constitute or imply its endorsement, recommendation, or favoring by the United States Government or any agency thereof. The views and opinions of authors expressed herein do not necessarily state or reflect those of the United States Government or any agency thereof.

\section{Availability}

This report is posted on the U.S. Department of Energy's Princeton Plasma Physics Laboratory Publications and Reports web site in Fiscal Year 2004. The home page for PPPL Reports and Publications is: http://www.pppl.gov/pub_report/

DOE and DOE Contractors can obtain copies of this report from:

U.S. Department of Energy

Office of Scientific and Technical Information

DOE Technical Information Services (DTIS)

P.O. Box 62

Oak Ridge, TN 37831

Telephone: (865) 576-8401

Fax: (865) 576-5728

Email: reports@adonis.osti.gov

This report is available to the general public from:

National Technical Information Service

U.S. Department of Commerce

5285 Port Royal Road

Springfield, VA 22161

Telephone: $1-800-553-6847$ or

(703) $605-6000$

Fax: (703) 321-8547

Internet: http://www.ntis.gov/ordering.htm 


\title{
Images of Complex Interactions of an Intense Ion Beam with Plasma Electrons
}

\author{
Igor D. Kaganovich, Edward Startsev, and Ronald C. Davidson
}

\begin{abstract}
Ion beam propagation in a background plasma is an important scientific issue for many practical applications. The process of ion beam charge and current neutralization is complex because plasma electrons move in strong electric and magnetic fields of the beam. Computer simulation images of plasma interaction with an intense ion beam pulse are presented.
\end{abstract}

Plasma neutralization of an intense ion beam pulse is of interest for many applications, including plasma lenses, heavy ion fusion, high energy physics, etc. Comprehensive analytical, numerical and experimental studies are underway to investigate the complex interaction of a fast ion beam with a background plasma [1-5]. The positively charged ion beam attracts plasma electrons, and as a result, the plasma electrons have a tendency to neutralize the beam charge and current. An analytical electron fluid model has been developed to describe the plasma response to a propagating non-relativistic ion beam [1]. The model predicts very good charge neutralization during quasi-steady-state propagation, provided the beam pulse duration is much longer than the electron plasma period. In the opposite limit, the beam pulse excites large-amplitude plasma waves [3]. If the beam density is larger than plasma background density, the plasma waves break. Theoretical predictions are compared with the results of calculations utilizing a particle-in-cell (PIC) code. A suite of particle-in-cell codes has been developed to study the propagation of an ion beam pulse through the background plasma. The cold electron fluid results agree well with the PIC simulations for ion beam propagation through a background plasma. The reduced fluid description can provide an important benchmark for numerical codes and yield scaling relations for different beam and plasma parameters [3].

The movies produced by visualization of numerical simulation data show complex collective phenomena during beam entry and exit from the plasma $[3,4]$ and during beam propagation along a solenoidal magnetic field [5]. Note that movies of these results are available online $[3,4]$.

Figure 1 shows the electron density perturbation during beam entry into the uniform background plasma in the presence of a solenoidal magnetic field along the beam propagation. Without solenoidal magnetic field the wake in the electron density is produced by the ion beam head and lags the ion beam density $[1,4,7]$. A presence of the external solenoidal magnetic field leads to the electron density perturbations propagation ahead of the beam. This makes the moving window computational approach applied for simulations inadequate after certain time when perturbation reach the front boundary (see Fig.1d), as it assumes unperturbed plasma ahead of the beam. The complete study of this phenomena is still in progress and shall be reported elsewhere.

Acknowledgment: This research was supported by the U.S. Department of Energy.

\section{REFERENCES}

[1] I. D. Kaganovich, G. Shvets, E. Startsev and R. C. Davidson, "Nonlinear charge and current neutralization of an ion beam pulse in a pre-formed plasma”, Phys. Plasmas 8, 4180 (2001).

[2] I. D. Kaganovich, E. Startsev and R. C. Davidson, "Analytical and Numerical Studies of Heavy Ion Beam Transport In the Fusion Chamber", Laser and Particle Beams 20, 497 (2002).

[3] I.D. Kaganovich, E. A. Startsev and R. C. Davidson, Phys.

Plasmas "Nonlinear plasma waves excitation by intense ion beams in background plasma”, Phys. Plasmas 11, 3546 (2004). http://www.pppl.gov/pub_report//2004/PPPL-3942-abs.html

[4] I. D. Kaganovich, E. Startsev and R. C. Davidson, "Analytical and numerical studies of the complex interaction of a fast ion beam pulse with a background plasma”, Physica Scripta T107, 54 (2004), invited paper at ITCPP “Complex Plasma in New Millenium” 2003, Santorini, Greece. http://www.pppl.gov/pub_report//2004/PPPL3909-abs.html

[5] I. D. Kaganovich, E. A. Startsev and R. C. Davidson, "Ion Beam Pulse Neutralization by a Background Plasma in a Solenoidal Magnetic Field," Proceedings of 2004 International symposium on Heavy Ion Fusion Princeton, NJ; submitted to Nuclear Instruments and Methods in Physics Research A, (2004).

[6] http://www.trilobites.com.

[7] I. D. Kaganovich, E. A. Startsev, S. Klasky and R. C. Davidson, IEEE Trans. Plasma Science 30, 12 (2002).

\section{Figure captions}

Fig.1 Neutralization of an ion beam pulse during its propagation through a cold, uniform, background plasma in planar geometry with an external uniform magnetic field. The beam propagates in the y-direction. The beam velocity is $V_{b}=0.5 c$, the beam density is $n_{b}=0.5 n_{p}$, where $n_{p}$ is the background density, and the ion beam charge state is $\mathrm{Z}_{\mathrm{b}}=1$. The beam pulse dimensions are: the beam radius is equal to 1.5 of the skin depth $\left(c / \omega_{e p}\right)$ and half length is $7.5 c / \omega_{e p}$. Here, $\omega_{e p}$ is the electron plasma frequency, $c$ is the speed of light in vacuum. The external magnetic field corresponds to the electron cyclotron frequency $\omega_{e c}=5 \omega_{e p}$. Shown in the figure are color plots of the normalized density $\left(n / n_{p}\right)$ obtained in particle-incell simulations in $\left(\omega_{e p} x / c, \omega_{e p} y / c\right)$ space, (a) the beam pulse density (b)-(d) the electron density after beam enters plasma at times: (b) $132 / \omega_{e p}$, (c) $172 / \omega_{e p}$, and (d) $200 / \omega_{e p}$. Figure 1 (e) shows the photo of the trilobite [6]. 
(a)
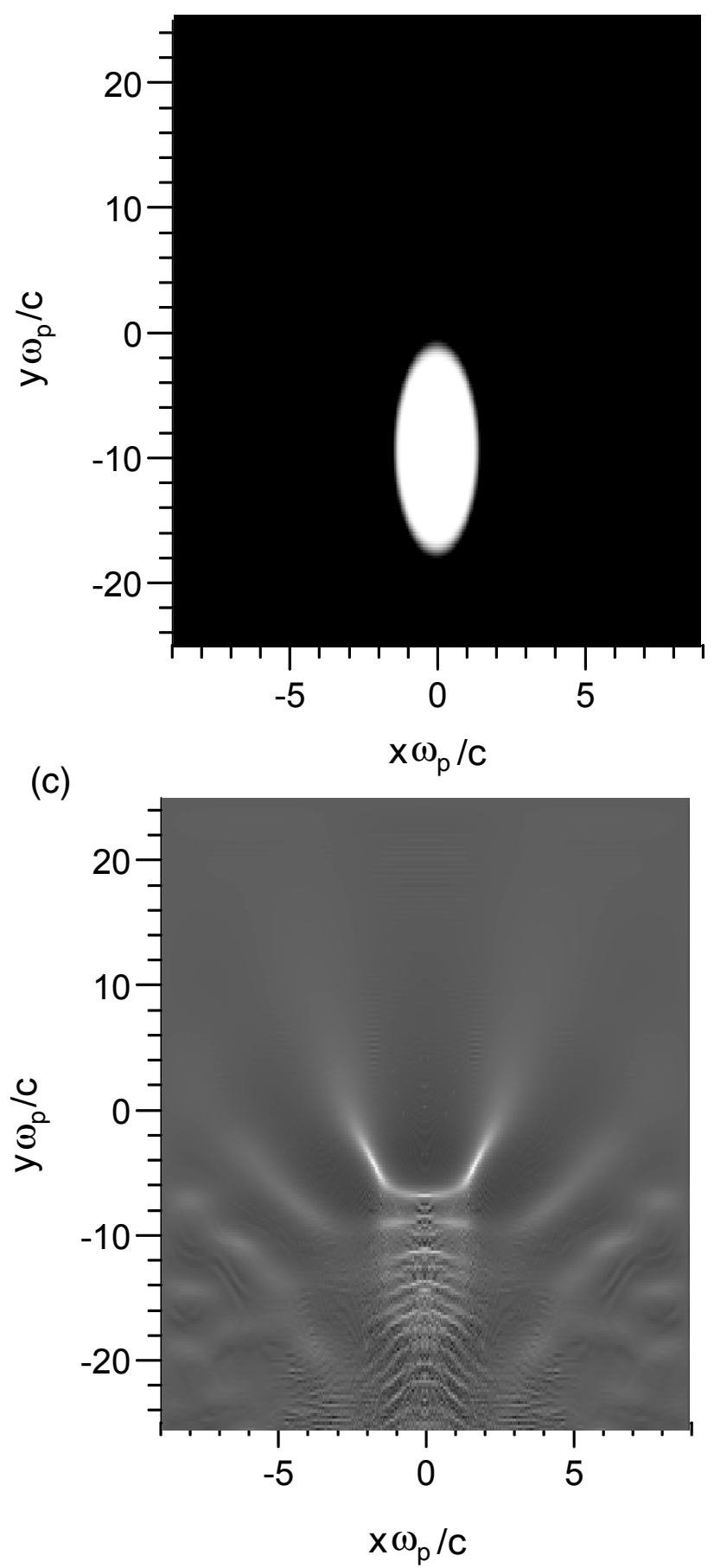

(e)

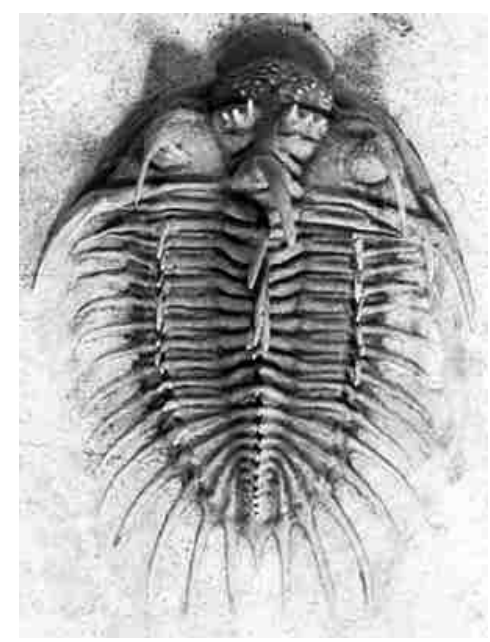

(b)
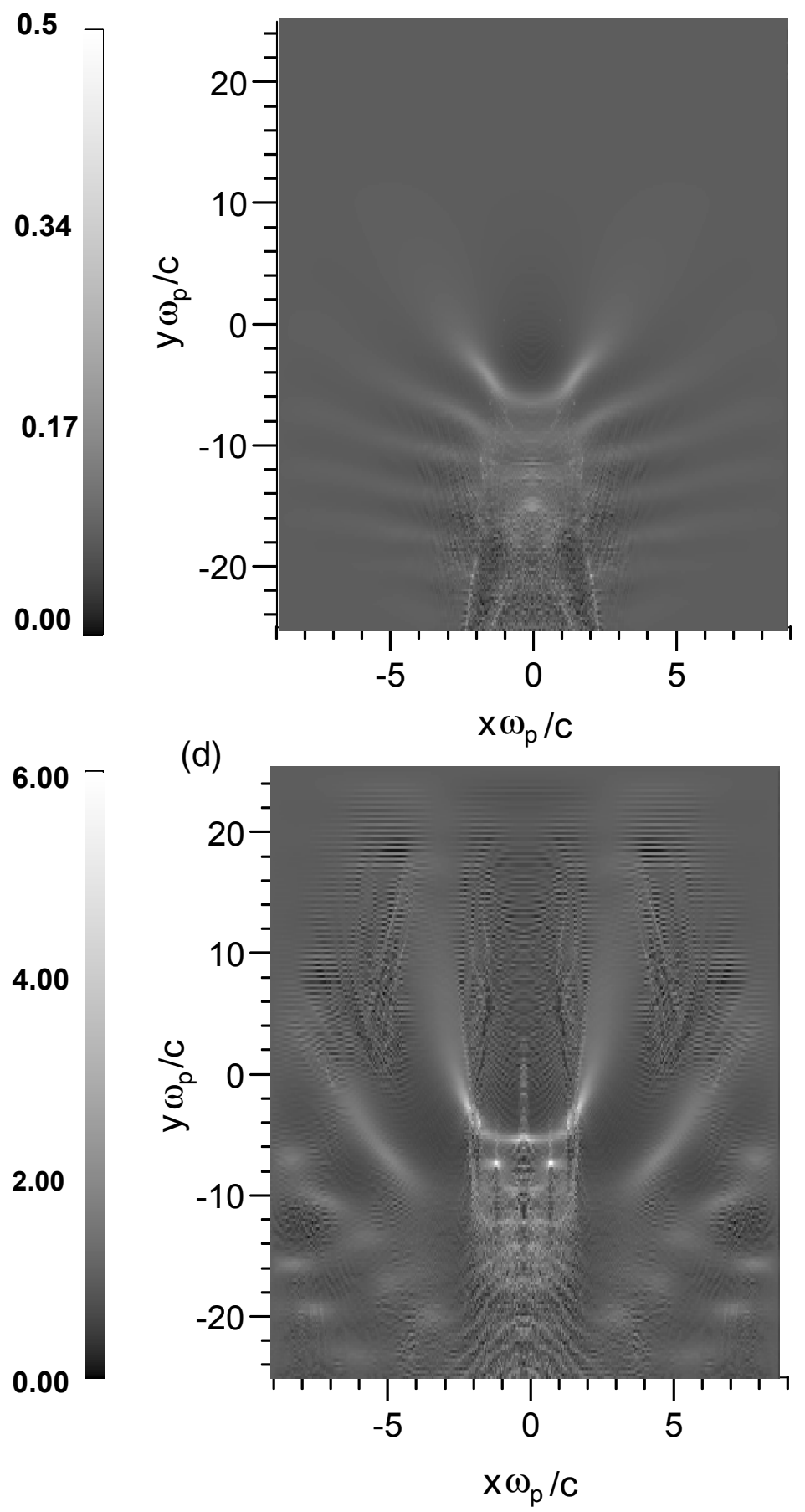

4.00

2.00

0.00

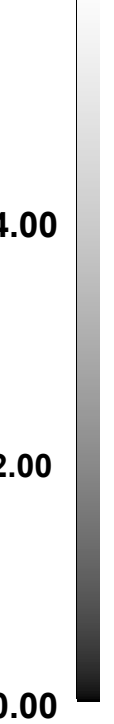




\section{External Distribution}

Plasma Research Laboratory, Australian National University, Australia

Professor I.R. Jones, Flinders University, Australia

Professor João Canalle, Instituto de Fisica DEQ/IF - UERJ, Brazil

Mr. Gerson O. Ludwig, Instituto Nacional de Pesquisas, Brazil

Dr. P.H. Sakanaka, Instituto Fisica, Brazil

The Librarian, Culham Laboratory, England

Mrs. S.A. Hutchinson, JET Library, England

Professor M.N. Bussac, Ecole Polytechnique, France

Librarian, Max-Planck-Institut für Plasmaphysik, Germany

Jolan Moldvai, Reports Library, Hungarian Academy of Sciences, Central Research Institute for Physics, Hungary

Dr. P. Kaw, Institute for Plasma Research, India

Ms. P.J. Pathak, Librarian, Institute for Plasma Research, India

Ms. Clelia De Palo, Associazione EURATOM-ENEA, Italy

Dr. G. Grosso, Instituto di Fisica del Plasma, Italy

Librarian, Naka Fusion Research Establishment, JAERI, Japan

Library, Laboratory for Complex Energy Processes, Institute for Advanced Study, Kyoto University, Japan

Research Information Center, National Institute for Fusion Science, Japan

Dr. O. Mitarai, Kyushu Tokai University, Japan

Dr. Jiangang Li, Institute of Plasma Physics, Chinese Academy of Sciences, People's Republic of China

Professor Yuping Huo, School of Physical Science and Technology, People's Republic of China

Library, Academia Sinica, Institute of Plasma Physics, People's Republic of China

Librarian, Institute of Physics, Chinese Academy of Sciences, People's Republic of China

Dr. S. Mirnov, TRINITI, Troitsk, Russian Federation, Russia

Dr. V.S. Strelkov, Kurchatov Institute, Russian Federation, Russia

Professor Peter Lukac, Katedra Fyziky Plazmy MFF UK, Mlynska dolina F-2, Komenskeho Univerzita, SK-842 15 Bratislava, Slovakia

Dr. G.S. Lee, Korea Basic Science Institute, South Korea

Institute for Plasma Research, University of Maryland, USA

Librarian, Fusion Energy Division, Oak Ridge National Laboratory, USA

Librarian, Institute of Fusion Studies, University of Texas, USA

Librarian, Magnetic Fusion Program, Lawrence Livermore National Laboratory, USA

Library, General Atomics, USA

Plasma Physics Group, Fusion Energy Research Program, University of California at San Diego, USA

Plasma Physics Library, Columbia University, USA

Alkesh Punjabi, Center for Fusion Research and Training, Hampton University, USA

Dr. W.M. Stacey, Fusion Research Center, Georgia Institute of Technology, USA

Dr. John Willis, U.S. Department of Energy, Office of Fusion Energy Sciences, USA

Mr. Paul H. Wright, Indianapolis, Indiana, USA 
The Princeton Plasma Physics Laboratory is operated by Princeton University under contract with the U.S. Department of Energy.

\author{
Information Services \\ Princeton Plasma Physics Laboratory \\ P.O. Box 451 \\ Princeton, NJ 08543
}

Phone: 609-243-2750

Fax: 609-243-2751

e-mail: pppl_info@pppl.gov

Internet Address: http://www.pppl.gov 